\title{
The role of weather in idiopathic sudden sensorineural hearing loss
}

\author{
İdiyopatik ani sensörinöral işitme kaybında hava durumunun rolü
}

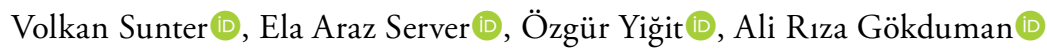

Department of Otolaryngology, Istanbul Training and Research Hospital, Istanbul, Turkey

\begin{abstract}
Objectives: This study aims to investigate the role of meteorological conditions in the etiology of idiopathic sudden sensorineural hearing loss (ISSHL) in patients living in Istanbul.

Patients and Methods: In the study, between January 1, 2008 and May 31, 2015, records of 670 patients (379 males, 291 females; mean age $45.3 \pm 15.6$ years; range, 10 to 98 years) with a referring diagnosis of ISSHL were examined retrospectively. Weather parameters used in the comparison were mean daily temperature $\left({ }^{\circ} \mathrm{C}\right)$, mean humidity (\%), mean wind speed (meter/second), and mean atmospheric pressure (hectopascal).
\end{abstract}

Results: Idiopathic sudden sensorineural hearing loss was most frequently seen in the months of March, April, May, and June. The mean atmospheric pressures were statistically lower $(\mathrm{p}=0.005)$ on ISSHL-related (positive) days than on ISSHL-unrelated (negative) days. Humidity was significantly higher on positive days $(\mathrm{p}=0.002)$. The mean temperature was significantly higher on positive days than on negative days $(\mathrm{p}<0.001)$.

Conclusion: Idiopathic sudden sensorineural hearing loss is more frequently seen in the spring. Low atmospheric pressure, high temperature, and high humidity are associated with ISSHL.

Keywords: Etiology, idiopathic sudden sensorineural hearing loss, meteorological condition, weather.

Sudden hearing loss is defined as a rapid onset (within 72 hours) of sensorineural hearing loss (more than $30 \mathrm{~dB}$ hearing loss in at least three consecutive frequencies) that can affect one or both ears. Sudden hearing loss affects five
$\ddot{O} Z$

Amaç: Bu çalışmada İstanbul'da yaşayan hastalarda idiyopatik ani sensörinöral işitme kaybının (İASNIKK) etiyolojisinde meteorolojik koşulların rolü araştırıldı.

Hastalar ve Yöntemler: Çalışmada 1 Ocak 2008 ve 31 Mayıs 2015 tarihleri arasında İASNIKK tanısı ile başvuran 670 hastanın (379 erkek, 291 kadın; ort. yaş $45.3 \pm 15.6$ yıl; dağılım, 10-98 yıl) kayıtları retrospektif olarak incelendi. Karşılaştırmada kullanılan hava parametreleri ortalama günlük sıcaklık $\left({ }^{\circ} \mathrm{C}\right)$, ortalama nem $(\%)$, ortalama rüzgar hızı (metre/ saniye) ve ortalama atmosfer basıncı (hektopaskal) idi.

Bulgular: İdiyopatik ani sensörinöral işitme kaybı en sık Mart, Nisan, Mayıs ve Haziran aylarında görüldü. Ortalama atmosferik basınçlar İASNİK ile ilişkili (pozitif) günlerde İASNİK ile ilişkili olmayan (negatif) günlere göre istatistiksel olarak daha düşüktü $(\mathrm{p}=0.005)$. Nem pozitif günlerde anlamlı derecede daha yüksekti $(\mathrm{p}=0.002)$. Ortalama sıcaklık pozitif günlerde negatif günlere göre anlamlı derecede daha yüksekti $(\mathrm{p}<0.001)$.

Sonuç: İdiyopatik ani sensörinöral işitme kaybı ilkbaharda daha sık görülür. Düşük atmosfer basıncı, yüksek sıcaklık ve yüksek nem İASNİK ile ilişkilidir.

Anahtar sözcükler: Etiyoloji, idiyopatik ani sensörinöral işitme kaybı, meteorolojik koşul, hava.

to 20 people in a population of 100,000 people. ${ }^{[1]}$ Vascular problems, viral infections, trauma, and tumors are common causes; however, in $85 \%$ of patients, no underlying cause can be identified, despite adequate investigation. ${ }^{[1,2]}$

Received: January 03, 2020 Accepted: January 23, 2020 Published online: February 07, 2020

Correspondence: Volkan Sunter, MD. İstanbul Eğitim Araştırma Hastanesi Kulak Burun Boğaz Kliniği, 34098 Fatih, İstanbul, Türkiye. e-mail: avsunter@gmail.com 
Sudden changes in climatic conditions lead to various changes in human metabolism and can therefore play an important role in the etiology of various diseases. Viral infections, allergies, and some vascular diseases can also be affected by meteorological conditions. The most frequently studied meteorological parameters are air temperature, humidity, wind speed, and atmospheric pressure, and the relationship between meteorological conditions and diseases has been the topic of several studies. ${ }^{[3-8]}$ Nevertheless, few studies have examined the relationship between meteorological changes and idiopathic sudden sensorineural hearing loss (ISSHL), and the results have been controversial. ${ }^{[8-15]}$ Some studies have reported that weather conditions affect the occurrence of ISSHL, whereas others have found no correlation. ${ }^{[9-15]}$ The most likely reason for this controversy is that these studies included populations living in different regions of the world and in different climates.

Turkey is located at the junction of Asia and Europe, and three of its borders are surrounded by the sea. It is under the influence of many different climates, including Mediterranean, Black Sea, Balkan, and Anatolian continental climates. Two studies have evaluated the people living in this region; however, the study by Danielides et al. ${ }^{[12]}$ had a limited size, whereas the study by Gerçeker et al. ${ }^{[11]}$ included the population living in Ankara, which has a non-seaside continental climate. Neither of these studies examined the population living in Istanbul, which is a seaside city and under the influence predominantly of a Mediterranean climate. Therefore, in this study, we aimed to investigate the role of meteorological conditions in the etiology of ISSHL in patients living in Istanbul.

\section{PATIENTS AND METHODS}

Between January 1, 2008 and May 31, 2015, the medical records of 670 patients $(379$ males, 291 females; mean age $45.3 \pm 15$. 6 years; range, 10 to 98 years) who were admitted to Istanbul Training and Research Hospital and diagnosed with ISSHL were evaluated retrospectively. All patients included in the study resided on the European side of Istanbul. Medical and demographic characteristics of all patients were noted. Diagnosis of ISSHL was established after the exclusion of all other possible causes of sudden hearing loss. Patients with acute or chronic otitis media, diabetes mellitus, autoimmune disease, or a history of ototoxic drug usage, head trauma, and barotrauma were excluded. The study protocol was approved by the Istanbul Training and Research Hospital Ethics Committee. A written informed consent was obtained from each patient. The study was conducted in accordance with the principles of the Declaration of Helsinki.

All days between January 1, 2008 and May 31, 2015 were classified as positive (ISSHL-related) or negative (ISSHL-unrelated) days. Because of the delayed impact of meteorological conditions, the first day of hearing loss and the seven days before that day were identified as positive days on the calendar. The remaining days other than the positive days were identified as negative days. This classification was conducted separately for all patients.

All meteorological data were obtained from the local meteorological service. The nearest station to the place of residence of the patients was the Istanbul-Florya meteorological station, so data from that station were used. The weather parameters used in the comparison were the mean daily temperature $\left({ }^{\circ} \mathrm{C}\right)$, mean humidity (\%), mean wind speed (meter/second), and mean atmospheric pressure (hectopascal). We compared the positive and negative days for each patient using these parameters. The relationship between the seasons and ISSHL was also investigated.

\section{Statistical analysis}

The SPSS version 15.0 for Windows (SPSS Inc., Chicago, IL, USA) was used for statistical analysis. The descriptive statistics, the quantity and percentage

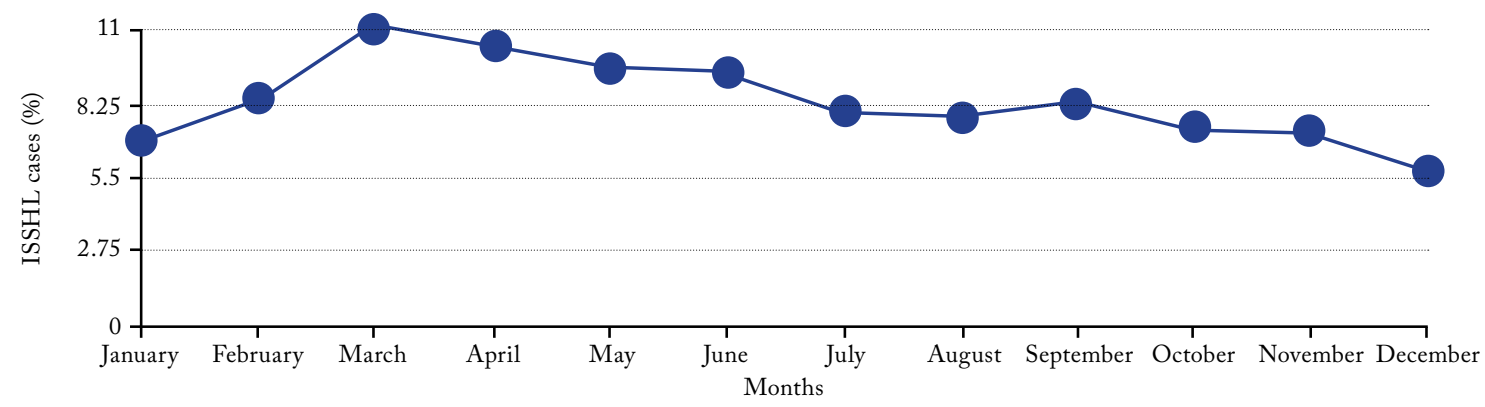

Figure 1. Monthly distributions of cases of idiopathic sudden sensorineural hearing loss.

ISSHL: Idiopathic sudden sensorineural hearing loss. 
for categorical variables, and the numeric variables are presented as the mean and standard deviation. Independent two-group comparisons were performed using the Mann-Whitney $U$ test because the numerical variables did not have a normal distribution. The proportions between groups for categorical variables were tested by chi-square analysis. An alpha level of $\mathrm{p}<0.05$ was considered statistically significant.

\section{RESULTS}

No statistically significant difference was found for gender or age among the patients $(p=0.287)$. The affected ears were the left ear in 201 (43.6\%) patients,

Table 1

Pressure means of idiopathic sudden sensorineural hearing loss positive and negative days

\begin{tabular}{|c|c|c|c|}
\hline & ISSHL+ & ISSHL- & \multirow[b]{2}{*}{$p$} \\
\hline & Mean \pm SD & Mean \pm SD & \\
\hline \multicolumn{4}{|c|}{$\begin{array}{l}\text { Atmospheric } \\
\text { pressure }\end{array}$} \\
\hline Total & $1011.4 \pm 6.4$ & $1012.0 \pm 6.4$ & 0.005 \\
\hline 2008 & $1013.8 \pm 8.1$ & $1012.5 \pm 6.5$ & 0.366 \\
\hline 2009 & $1011.0 \pm 5.1$ & $1011.0 \pm 6.4$ & 0.962 \\
\hline 2010 & $1009.7 \pm 6.2$ & $1010.6 \pm 4.8$ & 0.178 \\
\hline 2011 & $1013.0 \pm 6.5$ & $1013.4 \pm 5.6$ & 0.585 \\
\hline 2012 & $1011.4 \pm 6.3$ & $1011.7 \pm 7.0$ & 0.766 \\
\hline 2013 & $1011.1 \pm 6.4$ & $1017.2 \pm 6.7$ & $<0.001$ \\
\hline 2014 & $1010.6 \pm 5.9$ & $1011.9 \pm 5.7$ & 0.031 \\
\hline 2015 & $1013.6 \pm 6.3$ & $1012.9 \pm 7.9$ & 0.923 \\
\hline
\end{tabular}

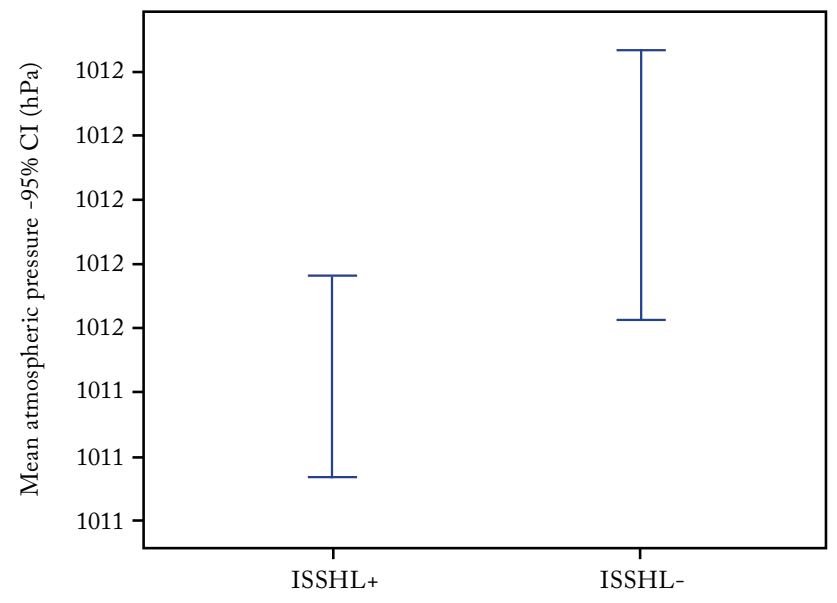

Figure 2. Pressure means of positive and negative days of idiopathic sudden sensorineural hearing loss.

CI: Confidence interval; hPa: Hectopascal; ISSHL: Idiopathic sudden sensorineural hearing loss. the right ear in $222(48.2 \%)$ patients, and bilateral ears in $38(8.2 \%)$ patients.

Idiopathic sudden sensorineural hearing loss was most commonly diagnosed in March, April, May, and June (Figure 1) and in the years between 2010 and 2013. The mean atmospheric pressure was statistically significantly lower $(\mathrm{p}=0.005)$ on positive days than on negative days (Table 1, Figure 2). Humidity was statistically significantly higher on positive days $(\mathrm{p}=0.002)$ (Table 2 and Figure 3). No difference was detected in mean wind speed between positive and negative days $(p=0.105)$ (Table 3 and Figure 4). The mean temperature was statistically significantly higher

Table 2

Humidity means of idiopathic sudden sensorineural hearing loss positive and negative days

\begin{tabular}{|ccccc|}
\hline & ISSHL + & & ISSHL- & \\
\cline { 2 - 2 } \cline { 5 - 5 } Mean \pm SD & & Mean \pm SD & $p$ \\
\hline Total & $75.0 \pm 10.3$ & & $73.4 \pm 10.6$ & 0.002 \\
2008 & $72.5 \pm 9.6$ & & $70.1 \pm 10.5$ & 0.043 \\
2009 & $72.8 \pm 11.3$ & & $72.0 \pm 11.8$ & 0.517 \\
2010 & $74.0 \pm 10.7$ & & $73.7 \pm 8.6$ & 0.824 \\
2011 & $74.1 \pm 9.4$ & & $73.7 \pm 8.6$ & 0.990 \\
2012 & $75.3 \pm 10.0$ & & $76.7 \pm 10.5$ & 0.266 \\
2013 & $76.5 \pm 11.2$ & & $77.2 \pm 9.9$ & 0.175 \\
2014 & $77.4 \pm 8.8$ & $78.7 \pm 8.4$ & 0.175 \\
2015 & $77.4 \pm 9.1$ & $75.9 \pm 8.8$ & 0.294 \\
\hline ISSHL: Idiopathic sudden sensorineural hearing loss; SD: Standard deviation.
\end{tabular}

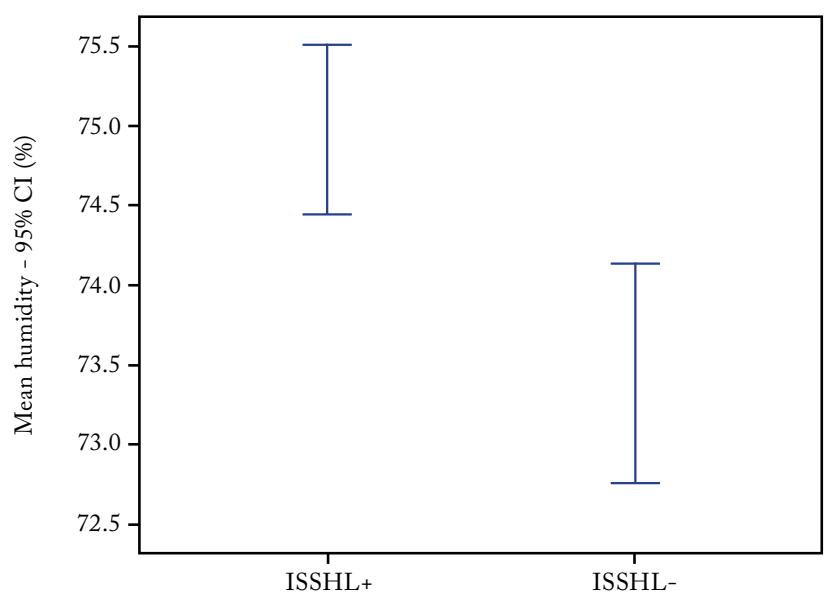

Figure 3. Humidity means of positive and negative days of idiopathic sudden sensorineural hearing loss.

CI: Confidence interval; ISSHL: Idiopathic sudden sensorineural hearing loss. 


\section{Table 3}

Wind speed means of idiopathic sudden sensorineural hearing loss positive and negative days

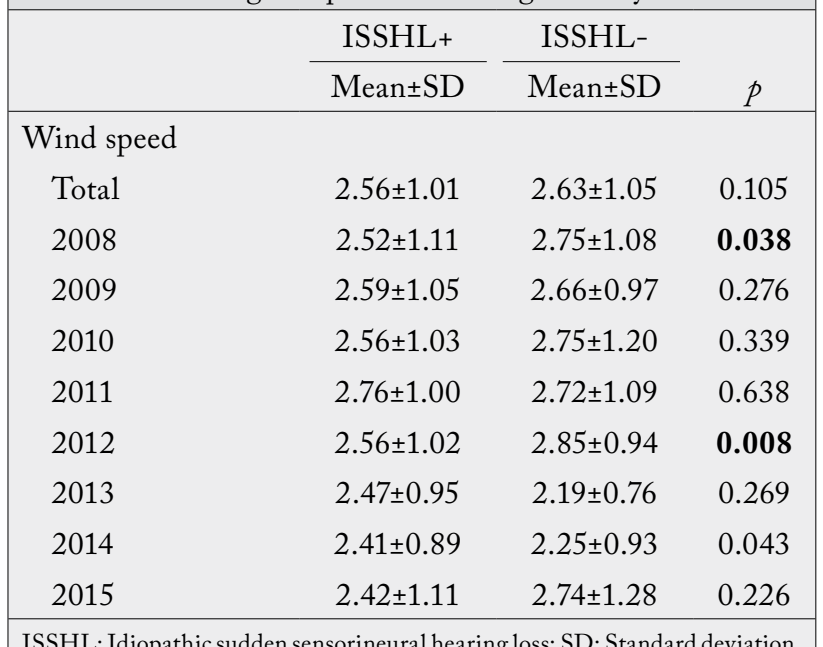

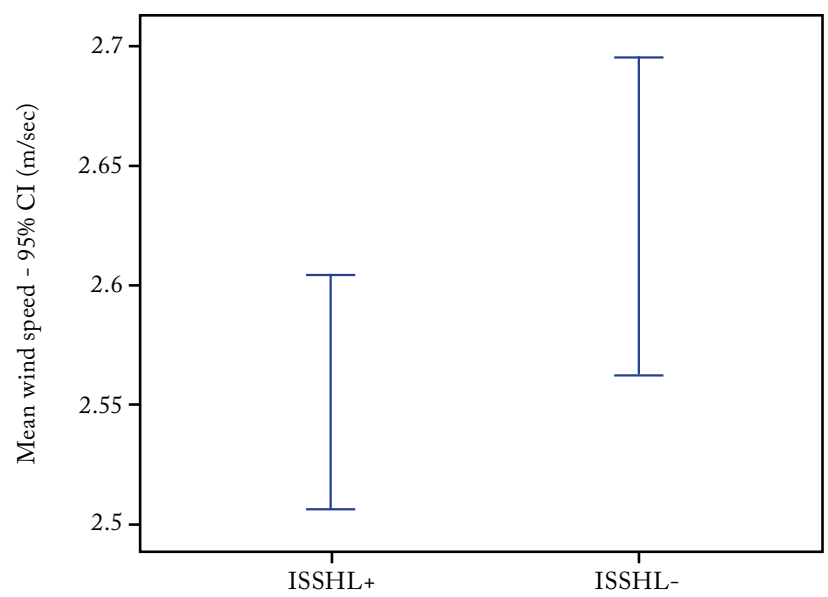

Figure 4. Wind speed means of positive and negative days of idiopathic sudden sensorineural hearing loss.

CI: Confidence interval; ISSHL: Idiopathic sudden sensorineural hearing loss; m: Meter; sec: Second.

on positive days than on negative days $(\mathrm{p}<0.001)$ (Table 4, Figure 5).

\section{DISCUSSION}

In the present study, we evaluated whether the meteorological conditions affect the etiology of ISSHL in a seaside community. Our results indicated an increased frequency of ISSHL on humid and hot days, which are days associated with high atmospheric pressure, between the years of 2008 and 2015 in Istanbul. Furthermore, an increase in the incidence of ISSHL was detected during the spring months. These

\section{Table 4}

Temperature means of idiopathic sudden sensorineural hearing loss positive and negative days

\begin{tabular}{|lccccc}
\hline & ISSHL + & & ISSHL- & \\
\cline { 2 - 2 } Temperature & Mean \pm SD & & Mean \pm SD & & $p$ \\
Total & & & \\
2008 & $15.7 \pm 7.3$ & & $14.4 \pm 7.5$ & $<\mathbf{0 . 0 0 1}$ \\
2009 & $12.8 \pm 7.1$ & & $16.2 \pm 7.3$ & $<\mathbf{0 . 0 0 1}$ \\
2010 & $15.6 \pm 6.3$ & & $15.5 \pm 7.3$ & 0.878 \\
2011 & $16.0 \pm 7.5$ & & $15.4 \pm 7.3$ & 0.489 \\
2012 & $14.8 \pm 7.3$ & & $11.4 \pm 7.4$ & $\mathbf{0 . 0 0 1}$ \\
2013 & $16.5 \pm 7.6$ & & $11.9 \pm 9.8$ & $<\mathbf{0 . 0 0 1}$ \\
2014 & $15.8 \pm 7.2$ & & $8.9 \pm 3.6$ & $<\mathbf{0 . 0 0 1}$ \\
2015 & $18.5 \pm 6.5$ & & $14.1 \pm 6.2$ & $<\mathbf{0 . 0 0 1}$ \\
\cline { 1 - 1 } & $6.0 \pm 4.7$ & & $8.7 \pm 5.4$ & 0.085 \\
\hline
\end{tabular}

ISSHL: Idiopathic sudden sensorineural hearing loss; SD: Standard deviation.

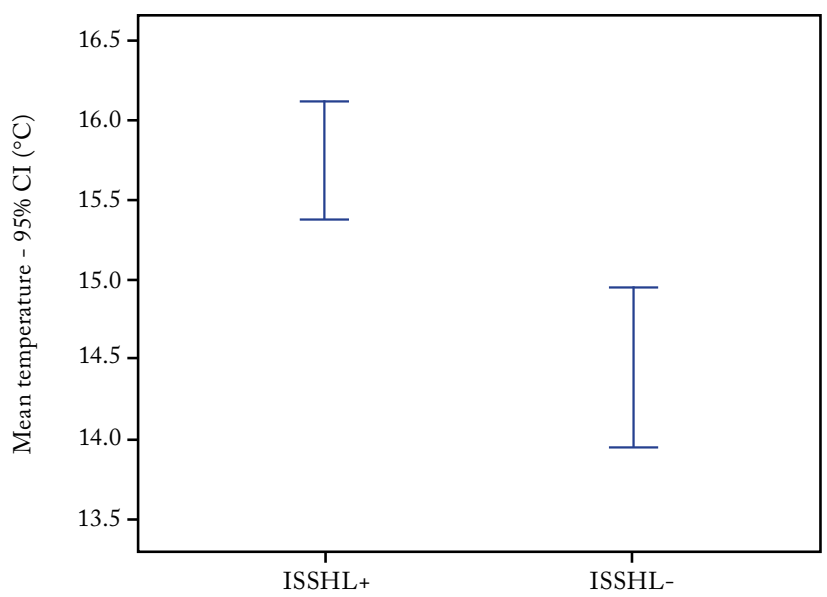

Figure 5. Temperature means of positive and negative days of idiopathic sudden sensorineural hearing loss.

CI: Confidence interval; ISSHL: Idiopathic sudden sensorineural hearing loss.

findings suggest that climate change and seasons may be important etiologic factors of ISSHL.

Hippocrates first reported a relationship between weather and several diseases. ${ }^{[7]}$ Since those ancient times, many studies have investigated the relationship between the climate and disorders such as stroke, myocardial infarction, migraine, and many infectious diseases. ${ }^{[1-7]}$ Some studies have demonstrated the effects of changes in the weather on ISSHL. ${ }^{[8-15]}$

The etiology of idiopathic hearing loss is quite complicated and full of unknowns. The most widely accepted theories regarding the etiology of ISSHLinvolve 
viral and vascular causes. ${ }^{[1,2]}$ Invasion of herpes simplex or neurotropic viruses, such as cytomegalovirus, into the cochlea and the cochlear nerve is proposed to explain the theory of a viral etiology of ISSHL.${ }^{[16]}$ In accordance with the viral cause theory, the occurrence of upper respiratory tract infections caused by viral infections is closely related to the meteorological parameters. ${ }^{[5,17]}$ For example, du Prel et al. ${ }^{[17]}$ reported that the incidences of influenza virus, respiratory syncytial virus, and adenovirus infections were correlated with temperature, and that rhinovirus infection was relatively humidity related. In our study, we observed that ISSHL was more frequent in hot weather and that humidity promoted the occurrence of ISSHL. From this point of view, although a viral etiology has not been widely approved, the fact that viral infections are commonly linked to weather conditions hence, an increase in viral infections could explain an increased incidence of ISSHL.

The vascular theory of hearing loss etiology is supported by the observation that obstructions in the cochlear blood flow can lead to hearing loss; thereby, confirming a relationship between cardiovascular risk factors and sudden hearing loss. ${ }^{[18]}$ Other studies have suggested a relationship between cardiovascular disease and meteorological conditions. ${ }^{[5,19]}$ For example, a large-scale study by Schwartz et al. ${ }^{[5]}$ determined that mortality rates due to circulatory failure were closely related to influenza incidence, dew point temperature, and barometric pressure. In our study, the observed relationship between a change in atmospheric pressure and an increase in ISSHL supports both the vascular and the viral etiologic factor theories.

Several studies have demonstrated the effects of weather changes on ISSHL, but weather conditions have not been identified as an etiological factor in diagnostic guidelines. ${ }^{[1,2]}$ Some of these studies focused on seasonal changes, whereas others centered on climate change; hence, different and contradictory results were reported. Similar to our findings, Herbert et al ${ }^{[8]}$ and Mees et al. ${ }^{[9]}$ showed that low atmospheric pressure might play a role in the etiology of ISSHL. By contrast, Danielides et al., ${ }^{[12]}$ in a series of 82 cases, found no significant relationship between weather parameters and ISSHL. Lin et al., ${ }^{[13]}$ in a series of 8,712 cases, failed to find any significant relationship between monthly weather parameters and ISSHL.

Seo et al., ${ }^{[10]}$ in a series of 607 cases, showed a relationship between ISSHL and strong wind speeds five days before ISSHL onset, while no relationship was detected between other parameters, such as temperature, humidity, and atmospheric pressure. Unlike these studies, in our study, the wind speed had no significant effect on ISSHL. However, the study by Seo at al., ${ }^{[10]}$ which was based on the monthly mean values of weather parameters during the assessment, ignored the variability in daily weather parameters. Many meteorological parameters, such as temperature, humidity, wind speed, and atmospheric pressure, may fluctuate daily. In our study, meteorological data were received on a daily basis. The daily changes indicated a low mean pressure $(\mathrm{p}=0.005)$, a high mean humidity $(\mathrm{p}=0.002)$, and a high mean temperature $(\mathrm{p}<0.001)$.

Among the studies that have investigated the relationship between climate changes and diseases, Schwartz et al..$^{[5]}$ evaluated the relationship between cardiovascular mortality and climate factors in a very crowded sample of $71,354,000$ people scattered over a very large geographical region. The authors concluded that temperature had a variable effect depending upon the location and indicated that people become accustomed to their local temperature cycles. ${ }^{[5]}$ Istanbul is under the influence of the Mediterranean, Black Sea, and Terrestrial climates, with a mean monthly temperature that ranges from $5.7^{\circ} \mathrm{C}$ (January) to $23.1^{\circ} \mathrm{C}$ (August). Among similar studies, the study by Danielides et al. ${ }^{[12]}$ was performed in a climate most similar to that of Istanbul. They reported no seasonal or climatic effects in their study; however, they included only a limited number of patients. A study from Turkey by Gerçeker et al. ${ }^{[11]}$ investigated the relationship of hearing loss with seasons. Their series of 164 cases living in Ankara, which is dominated by a continental climate, revealed that a relationship was most frequently evident in the spring, similar to our findings. These increases in the spring can be associated with low atmospheric pressure that, in turn, is associated with an increased incidence of vascular disease. These findings support the role of vascular events due to pressure changes in the etiology of ISSHL, although they do not completely exclude the viral theory.

Our study is important in terms of having the largest population to date to show a relationship between ISSHL and meteorological effects on people living on the seashore. The most important limitations of our study were that the presence of any possible upper respiratory tract infections was disregarded within the study population, additional studies on viral pathogens were lacking in this population, and the patients' healing outcomes were not assessed.

In conclusion, we found that low atmospheric pressure, high temperature, and high humidity were correlated with ISSHL and that ISSHL was most frequently seen in spring. Further studies are needed to determine the direct or indirect roles of meteorological conditions in the etiology of ISSHL. 


\section{Declaration of conflicting interests}

The authors declared no conflicts of interest with respect to the authorship and/or publication of this article.

\section{Funding}

The authors received no financial support for the research and/or authorship of this article.

\section{REFERENCES}

1. Stachler RJ, Chandrasekhar SS, Archer SM, Rosenfeld RM, Schwartz SR, Barrs DM, et al. Clinical practice guideline: sudden hearing loss. Otolaryngol Head Neck Surg 2012;146:S1-35.

2. Levie P, Desgain O, de Burbure C, Germonpré P, Monnoye JP, Thil MP, et al. Sudden hearing loss. B-ENT 2007;3:33-43.

3. Schmidt W, Sarran C, Ronan N, Barrett G, Whinney DJ, Fleming LE, et al. The Weather and Ménière's Disease: A Longitudinal Analysis in the UK. Otol Neurotol 2017;38:225-33.

4. Ozpolat B, Gözübüyük A, Koçer B, Yazkan R, Dural $\mathrm{K}$, Genç O. Meteorological conditions related to the onset of spontaneous pneumothorax. Tohoku J Exp Med 2009;217:329-34.

5. Schwartz BG, Qualls C, Kloner RA, Laskey WK. Relation of total and cardiovascular death rates to climate system, temperature, barometric pressure, and respiratory infection. Am J Cardiol 2015;116:1290-7.

6. Ozeki K, Noda T, Nakamura M, Ojima T. Weather and headache onset: a large-scale study of headache medicine purchases. Int J Biometeorol 2015;59:447-51.

7. Falagas ME, Bliziotis IA, Kosmidis J, Daikos GK. Unusual climatic conditions and infectious diseases: observations made by Hippocrates. Enferm Infecc Microbiol Clin 2010;28:716-8.

8. Herbert I, Nolte E, Eichhorn T. Weather status and incidence of idiopathic facial nerve paralyses, vestibular disorders, Menière's attacks and sudden deafness. Laryngol
Rhinol Otol 1987;66:249-50.

9. Mees K, Ruhenstroth-Bauer G, Sandhagen R, Baumer $\mathrm{H}$, Filipiak B. Idiopathic hearing loss--dependent on the weather?. Laryngol Rhinol Otol 1987;66:246-8.

10. Seo JH, Jeon EJ, Park YS, Kim J, Chang KH, Yeo SW. Meteorological conditions related to the onset of idiopathic sudden sensorineural hearing loss. Yonsei Med J 2014;55:1678-82.

11. Gerceker M, Ugur K, Serife G, Mustafa K, Muderris T, Tataragasi A. Does seasonal variation have an effect on the tendency and severity of idiopathic sudden sensorineural hearing loss? Int Adv Otol 2011;7:67-70.

12. Danielides V, Nousia CS, Bartzokas A, Lolis CJ, Kateri $\mathrm{M}$, Skevas A. Weather conditions and sudden sensorineural hearing loss. BMC Ear Nose Throat Disord 2002;2:2.

13. Lin HC, Lee HC, Chao PZ, Wu CS. The effects of weather on the incidence of sudden sensorineural hearing loss: a 5-year population-based study. Audiol Neurootol 2006;11:165-71.

14. Mizukoshi K, Watanabe Y, Shojaku H, Ito M, Ishikawa $\mathrm{M}$, Aso S, et al. Influence of a cold front upon the onset of Meniére's disease in Toyama, Japan. Acta Otolaryngol Suppl 1995;520:412-4.

15. Preyer S. Effect of weather on the incidence of sudden deafness. Laryngorhinootologie 1996;75:443-6.

16. Rabinstein A, Jerry J, Saraf-Lavi E, Sklar E, Bradley WG. Sudden sensorineural hearing loss associated with herpes simplex virus type 1 infection. Neurology 2001;56:571-2.

17. du Prel JB, Puppe W, Gröndahl B, Knuf M, Weigl JA, Schaaff F, et al. Are meteorological parameters associated with acute respiratory tract infections? Clin Infect Dis 2009;49:861-8.

18. Ciccone MM, Cortese F, Pinto M, Di Teo C, Fornarelli F, Gesualdo M, et al. Endothelial function and cardiovascular risk in patients with idiopathic sudden sensorineural hearing loss. Atherosclerosis 2012;225:511-6.

19. Verberkmoes NJ, Soliman Hamad MA, Ter Woorst JF, Tan $\mathrm{ME}$, Peels $\mathrm{CH}$, van Straten AH. Impact of temperature and atmospheric pressure on the incidence of major acute cardiovascular events. Neth Heart J 2012;20:193-6. 